\title{
IMPLIKASI TERBITNYA REGULASI TENTANG PERTIMAHAN TERHADAP HUBUNGAN ANTARA BOS DAN ANAK BUAH (SEBUAH EGALITARINAISME LOKAL)
}

\author{
Citra Asmara Indra, S.Sos., M.A*
}

\begin{abstract}
Abtract
Regulatory changes on tin by the central government or the entrance slit for local governments to take over the management of tin strengthened by the release of law on regional autonomy. Government then uses its authority to issue a local regulation that allows the general public to mine tin unconventional. Unconventional means parties other than the two mining companies, namely PT. Timah Tbk. and PT. Koba Tin has monopolized the management of lead since the Dutch colonial era, and those who become partners of both companies. Law is a legal umbrella for the people from different walks to mine tin massively without any consequences to reclaim their land dug. The implications of rising regulation of the dynamics of tin tin mining in Bangka Belitung province, particularly in Lampur village, Central Bangka regency, then look at the pattern of the relationship between the boss and the tin men in connection with the issuance of these regulations on the lives of the miners.
\end{abstract}

\section{Key Words :}

Regulation, Minners, and Egalitarism

\section{PENDAHULUAN}

Monopolistik dan sentralistik pertimahan di Pulau Bangka dan Belitung secara periodesasi dimulai pada masa VOC tahun 1819, dari Pemerintah Kolonial Belanda dan dilanjutkan oleh Pemerintah Indonesia terutama sejak tahun 1953 ketika Banka Tin Winning (BTW) sebutan untuk perusahaan pengelolaan timah yang berada dibawah kendali negara dinasionalisasikan. Pemerintah Indonesia mengikuti kebijakan mineral Pemerintah Kolonial yang menganggap timah seperti halnya batu bara dan minyak sebagai komoditas strategis yang harus diawasi oleh negara baik dalam eksploitasinya maupun perdagangannya (Erman, 1994). Selama Orde Baru,

\footnotetext{
* Penulis adalah Dosen pada Jurusan Sosiologi, Fakultas Ilmu Sosial dan Ilmu Politik, Universitas Bangka Belitung.
}

pemerintah telah melakukan reorganisasi dan restrukturalisasi perusahaan negara, termasuk di dalamnya di sektor pertambangan timah, yaitu tepatnya pada tahun 1976 mengubah struktur perusahaan dari Perusahaan Negara atau PN. Tambang Timah Indonesia menjadi Perusahaan Terbatas atau PT. Tambang Timah (Persero).

Krisis moneter pada tahun 1997 dan periode pasca-Suharto membawa perubahan penting dalam sistem politik dan pengelolaan penambangan timah. Selama ini timah di Kepulauan Bangka Belitung dikelola secara penuh di bawah kendali Pemerintah Pusat. UU Nomor 11 Tahun 1967 (lihat lampiran) yang diperkuat oleh PP Nomor 27 Tahun 1980 (lihat juga dalam lampiran) mengatur bahwa timah adalah komoditas strategis negara dan oleh 
karenanya menjadi barang komoditas perdagangan yang diatur, diawasi, dan dilaksanakan oleh negara. Konsekuensinya adalah timah sebagai barang yang tidak bebas. PT. Timah, Tbk adalah satu-satunya perusahaan yang memiliki konsesi penambangan yang dimiliki oleh negara, sementara PT. Koba Tin yang $75 \%$ sahamnya dimiliki oleh asing tetap berada di bawah kontrol negara.

Dalam kurun waktu yang sangat lama, timah adalah komoditas yang tidak bisa disentuh bagi masyarakat lokal dalam berbagai bentuk. Kontrol Pemerintah Pusat atas komoditas timah begitu kuat sehingga mereka menggunakan tangan-tangan militer untuk melakukan proteksi sebagaimana dikatakan oleh (Erman, 2007: 230-231). Masyarakat lokal dilarang untuk menambang, menjual, bahkan menyimpannya walau satu kilogram pun. Kondisi ini menjadi prakondisi bagi munculnya disharmonisasi dalam pengelolaan timah di daerah ini.

Perubahan frontal pun terjadi pada tahun 1998 dengan dikeluarkannya Kepmenperindag Nomor 558/MPP/Kep/12/1998 (lihat dalam lampiran) tentang Ketentuan Umum di Bidang Ekspor yang tidak memuat timah sebagai barang yang diatur dan diawasi ekspornya. Keputusan ini tidak menempatkan komoditas timah sebagai komoditas strategis negara dan sebagai implikasinya timah kemudian menjadi barang bebas. Bebas karena Pemerintah Pusat tidak lagi menempatkannya sebagai komoditas yang seharusnya diatur dan diawasi ekspornya. Keputusan inilah sebetulnya yang paling awal menjadi pintu masuk bagi munculnya penambangan timah oleh masyarakat lokal secara langsung.
Kepmenperindag 558/1998 tersebut kemudian disusul oleh Kepmenperindag Nomor 146/MPP/Kep/4/1999 yang melakukan revisi terhadap barang-barang strategis negara dan lagi-lagi timah tidak masuk dalam salah satu barang yang hendak diatur dan diawasi ekspornya. Pada tahun yang sama, semangat desentralisasi kemudian mengalami penguatan seiring dengan munculnya UU Nomor 22 Tahun 1999 yang mengatur mengenai sistem pemerintahan daerah, disusul oleh UU Nomor 25 Tahun 1999 yang mengatur mengenai perimbangan keuangan pusat daerah. Dua UU tersebut menekankan mengenai kewenangan daerah, termasuk kewenangan untuk menerbitkan peraturan daerah.

Apa yang terjadi kemudian dapat ditebak. Masyarakat kemudian berlombalomba melakukan penambangan dengan menggunakan berbagai cara. Aktivitas penambangan timah secara masal yang dilakukan oleh masyarakat di Kepulauan Bangka Belitung ini dengan menambang timah secara inkonvensional atau dikenal dengan sebutan Timah Inkonvensional (TI). Timah Inkonvensional adalah aktivitas penambangan yang dilakukan oleh sekelompok masyarakat ataupun perorangan diluar mitra kerja PT. Timah, Tbk., dan PT. Koba Tin serta menggunakan mesin lebih dari 20PK (sebuah istilah penyebutan mesin untuk menggali timah, serta melakukan aktivitas penambangan di dalam atau di luar wilayah tambang yang telah ditetapkan oleh Pemerintah Daerah dalam Perda No. 6 Tahun 2001 tentang Peraturan Penambangan Timah). Selanjutnya dalam tulisan ini memakai istilah TI dipakai untuk menjelaskan segala bentuk aktivitas penambangan timah. Para pengusaha lokal menggunakan tenaga alat 
berat untuk mendapatkan timah, para pengusaha kelas menengah menggunakan alat-alat semprot, sementara para penambang kecil menggunakan tenaga manual dengan melimbang dan mengayak pasir-pasir timah. Ketiadaan regulasi pusat atas timah menyebabkan timah menjadi kontrol Pemerintah Daerah dan masyarakat secara langsung. Pemerintah Daerah memanfaatkan komoditas timah sebagai komoditas ekonomis dan politis, sementara masyarakat penambang memanfaatkan timah sebagai cara baru untuk masuk ke golongan ekonomi kelas atas.

Masyarakat bermetamorfosa dari masyarakat petani karet dan lada menjadi penambang. Para nelayan berlomba-lomba meninggalkan kapal lautnya untuk menghisap pasir-pasir timah di pesisir. Mereka yang bertahan dengan pekerjaan lamanya berhadapan dengan berbagai hal, misalnya keterbatasan lahan produktif karena diekspansi oleh penambangan timah, wilayah tangkap pesisir yang tercemar, dan degradasi lingkungan yang luas.

Dalam Kepmenperindag No. 558/1998 sendiri secara garis besar menyebutkan bahwa dalam rangka reformasi ekonomi nasional dan untuk meningkatkan daya saing, peningkatan ekspor serta menjamin kepastian dan kesinambungan bahan baku industri kecil dan menengah dengan mengubah status jenis barang tertentu yang semula termasuk kelompok barang yang dilarang dan bebas ekspornya menjadi kelompok barang yang diawasi ekspornya menjadi kelompok barang yang dilarang dan bebas ekspornya. Timah sebagaimana diketahui tidak tercantum, ke dalam jenis barang yang diatur ekspornya, maupun jenis barang yang diawasi ekspornya ataupun yang dilarang ekspornya. Akibat dari tidak tercantumnya timah sebagai barang yang termasuk ke dalam klausul Kepmenperindag No. 558/1998 kemudian menjadi pintu gerbang dari terbitnya sejumlah regulasi yang menjadikan timah sebagai komoditas bebas ekspor.

Dengan mengambil daerah penelitian di Desa Lampur, penelitian ini juga menguak bagaimana sebetulnya pola relasi kuasa dalam kehidupan penambangan Timah Inkonvensional. Perubahan regulasi memberikan perubahan dasar dalam relasirelasi sosial, terutama dalam kaitannya dengan sistem pertambangan timah rakyat. Cerita menarik mengenai bagaimana mereka yang tidak memiliki modal cukup kemudian menjadi bagian dari relasi kuasa ekonomis dan relasi kuasa sosial politis bos timah dibayangkan menjadi bagian tak terpisahkan dari cerita pertambangan timah di daerah ini.

Desa Lampur sebagai sebuah kawasan kaya timah menyajikan berbagai potensi yang menarik untuk dikaji. Pertama bahwa Lampur adalah sebuah kawasan yang sejak dulu menjadi simpul-simpul penambangan timah. Kejayaan timah pada masa lalu dapat dilihat pada dua hal, yakni keberadaan makam Tionghoa di daerah ini yang menjadi penanda eksistensi coolie timah Tionghoa dan keberadaan perumahan dan kawasan elit milik perusahaan timah pada tahun 1970-an. Artefak itu bisa dilihat hingga kini. Kedua, Lampur adalah daerah yang masih menyisakan kandungan timah yang banyak ditandai dengan munculnya camp-camp penambangan timah inkonvensial di banyak titik di kawasan ini. Lampur memang hanyalah sebuah desa secara administratif, namun menjadi daerah persilangan dua kabupaten dan beberapa kecamatan. 


\section{PEMBAHASAN}

Kuasa Dalam Regulasi Pertambangan Timah

\subsection{Di bawah UU No. 11 Tahun 1967}

Kendali Pemerintah Pusat atas timah yang dilakukan secara penuh pada masa Orde Baru, baik itu untuk dikelola oleh pertambangan timah maupun diserahkan kepada swasta ternyata tidak diimbangi dampaknya secara signifikan terhadap kondisi di daerah Bangka dan Belitung. Mekanisme sentralistik yang menjadi ciri khas pemerintah Orde Baru menjadi sebab awal permasalahan sistemik di Bangka Belitung. Dampak ekonomis pengelolaan timah pada masa Orde Baru membawa kekecewaan yang dalam terhadap penduduk dan pejabat daerah. Kondisi perlawanan ditampakkan tegas ketika Orde Baru tumbang melalui mekanisme yang memberikan celah bagi partisipasi daerah dan penduduk lokal untuk melakukan penambangan.

Pemerintahan Orde Baru memberlakukan UU No. 11/1967 (lihat dalam lampiran) tentang ketentuanketentuan pokok pertambangan. Timah sebagai komoditas strategis masuk dalam wilayah pengaturan negara. Dalih untuk kepentingan negara pada masa itu tidak menyebabkan resistensi di permukaan karena kebijakan Orde Baru adalah melakukan kontrol ketat atas pertimahan (Susilo \& Maemunah, 2009;53-55).

Erman (2007: 230-231) dalam bukunya mengatakan kontrol Pemerintah Pusat di Kepulauan Bangka Belitung ini sangat kuat pada masa Orde Baru dimana PT. Timah, Tbk menggunakan militer untuk memproteksi areal penambangan, melarang penduduk menambang timah, bahkan melarang penduduk menyimpan timah walau hanya $1 \mathrm{~kg}$ sekalipun, larangan keras memperdagangkannya, dan tentu saja kontrol Pemerintah Daerah bisa dikatakan sangat lemah atau hampir tidak ada sama sekali. Kepulauan Bangka Belitung terlebih pada Orde Baru hanyalah sebuah Daerah Tingkat II yang berada di wilayah Provinsi Sumatera Selatan. Persoalan ketidakadilan distribusi hasil kekayaan alam, yaitu timah yang ada di Provinsi Kepulauan Bangka Belitung tidak diprotes oleh masyarakat lokal sendiri karena Orde Baru menerapkan kebijakan sentralistis dan mementingkan stabilitas. Padahal arus kekayaan yang mengalir ke pusat dan Provinsi Sumatera Selatan pada saat itu begitu besar namun tidak diimbangi dengan perbaikan yang nyata bagi kehidupan masyarakat Kepulauan Bangka Belitung.

Situasi berbeda ketika masa awal berlakunya Otonomi Daerah. Ada desakan Pemerintah Daerah untuk memiliki saham PT. Timah, Tbk., tuntuan pengembalian bekas daerah penambangan, tuntutan pergantian direktur utama PT. Timah, Tbk., yang dijabat oleh orang Jawa kepada putra daerah, dan kritik-kritik mengenai transparansi manajemen perusahaan, serta anggapan ketidakpedulian PT. Timah, Tbk., terhadap kepentingan penduduk lokal (Erman, 2007: 231-233; Bangka Pos, 13/4/2011). Damanik (dalam Kompas 8/12/2001 sebagaimana dikutip Erman, 2007: 237-238) mengatakan bahwa menjamurnya TI sebenarnya tidak lepas dari faktor PT. Timah, Tbk., sendiri yaitu kurangnya kepedulian perusahaan terhadap masyarakat setempat, investasi keuntungan yang tidak berbasis kebutuhan lokal, tindakan keamanan perusahaan yang represif, dan kurang menjalin keharmonisan dengan pemerintah dan legislatif daerah.

Secara sederhana dapat dipahami bahwa pemanfaatan timah sebagai sumber 
ekonomi alternatif bagi masyarakat sebenarnya sudah berlangsung turuntemurun, namun monopoli hak pengelolaan oleh negara pada beberapa masa menyebabkan penambangan timah inkonvensional di daerah ini mudah ditelusuri penyebabnya. Sujitno (2007: 299) menyebut ini sebagai 'dendam sejarah' dimana otonomi daerah dipahami secara sederhana oleh sebagian anggota masyarakat sebagai hak lokal dalam mengelola timah di Provinsi Bangka Belitung.

\subsection{Bos dan Anak Buah : Sebuah Egalitarianisme Lokal}

Cooper (2010:17-18) berbicara tentang prinsip dari egalitarianisme dimana ada prinsip kegunaan yang menekankan kegunaan atau manfaat sebagai tolak ukur untuk menilai dan mengambil keputusan. Suatu tindakan atau keputusan dikatakan berguna apabila semakin banyak orang yang mendapatkan keuntungan dari tindakan tersebut. Prinsip ini berkaitan erat dengan dua premis, yakni pertama, manusia memiliki kemampuan yang sama untuk mengambil manfaat seperti rasa senang dari sesuatu yang pada dasarnya memberikan manfaat misalnya dari pendapatan, status, premis kedua, hal-hal seperti pendapatan, status akan cenderung mengalami kekurangan manfaat apabila telah mengalami pencapaian maksimum. Prinsip selanjutnya menurut Rawls (Cooper, 2010:25) adalah prinsip keadilan, yaitu ketidaksetaraan dalam sosial-ekonomi dalam masyarakat harus ditata sedemikian rupa sehingga kebijakan-kebijakan yang diambil pada akhirnya akan memberikan keuntungan sebesar-besarnya bagi mereka yang tidak beruntung.
Egaliterianisme Cooper dan Rawls dijadikan rujukan untuk menganalisis hubungan antara bos TI dan anak buah, ketika anak buah mempunyai posisi tawar untuk bisa bekerja dan berhenti kapan saja tanpa adanya keterikatan kontrak. Tetapi dalam dunia pertambangan, sulit ditemukan posisi egaliter murni dimana kesetaraan benar-benar dapat diterapkan walaupun hubungan antara bos TI dengan para penambang tidak seperti hubungan patron dan klien antara tuan tanah dan petani penggarap.

Terbitnya regulasi tentang pertimahan dimulai dengan UU. No. 11/1967 kemudian Kepmenperindag 558/1998 dan UU no. $22 / 1999$ yang pada intinya tidak mencantumkan timah sebagai komoditas strategis, sehingga menjadikan penambangan, perdagangan serta aktivitas penambangan yang berkaitan dengan timah sebagai jalan untuk mendapatkan kekayaan, keuntungan bagi para pelaku bisnis, aktoraktor politik maupun masyarakat lokal. Semua perubahan dikarenakan adanya perubahan regulasi pada level atas tersebut tentunya disertai dengan adanya konsekuensi terhadap kondisi ekonomi, politik maupun perubahan sosial pada masyarakat di Provinsi Kepulauan Bangka Belitung secara luas.

Pemerintah Daerah Kabupaten Bangka menanggapi terbitnya regulasi tentang pertimahan tersebut dengan mengeluarkan Perda No. 6 Tahun 2001, yang menjadikan Tambang Inkonvensional semakin bertambah banyak, dimana sebagian besar dimodali oleh pemilik modal berasal dari Jakarta, Singapura, dan daerah lain yang menggunakan orang lokal kepercayaan mereka, dan kemudian dikenal dengan sebutan cukong. Pengusaha timah umumnya yang dikenal adalah para pemilik 
TI, pemilik tambang besar mitra, dan pemilik perusahaan yang memperkerjakan langsung orang-orang untuk bekerja menghasilkan timah.

Sebagaimana namanya tambang inkonvensional, melakukan penambangan secara illegal. Ilegal dikarenakan penambangan tidak memiliki ijin, di lokasi yang tidak menjadi kuasa penambangannya atau karena lokasinya adalah hutan lindung dan fasilitas umum, dan karena jalur perdagangannya yang tidak legal. Para pemiliki TI menampung pekerja dengan upah yang relatif rendah sehingga akumulasi keuntungan yang didapatkan akan berlipat-lipat dibandingkan dengan yang dihasilkan oleh para penambang. Oleh karena sifatnya instan dan para pekerja di TI mendapatkan bayaran fluktuatif, mereka tetap menikmati pekerjaan sebagai penambang sekalipun sebenarnya pendapatan para majikan mereka berlipatlipat dari yang mereka hasilkan.

Bos TI yang memiliki modal besar umumnya merupakan mitra dari perusahaan yang memiliki kuasa penambangan resmi juga memperlakukan para pekerja tidak sesuai dengan standar. Tidak ada jaminan keselamatan kerja, gaji yang dinikmati di bawah para pemilik, serta tidak ada jaminan purna tugas menyebabkan para pekerja di tambang-tambang besar memiliki nasib yang tidak jauh berbeda dengan para penambang di tambang inkonvensional.

Dengan besarnya resiko selama penambangan timah berlangsung, maka keselamatan para penambang menjadi hal utama yang seharusnya diperhatikan oleh para Bos TI, namun faktanya, keselamatan para penambang seringkali terabaikan. Walaupun kecelakaan di lokasi penambangan kerap terjadi, namun tidak menyurutkan para pendatang untuk tetap terus berdatangan dari luar daerah Kepulauan Bangka Belitung dengan tujuan utama yaitu menjadi penambang TI dan seringkali mereka berdatangan atas rekomendasi keluarga atau teman mereka yang telah lebih dahulu datang menjadi penambang. Dengan hanya berbekal keinginan untuk mendapatkan penghasilan lebih layak, mereka menjadi penambang tanpa disertai dengan pengetahuan tentang keadaan tanah maupun kondisi daerah tambang. Bagi bos TI dengan modal kecil, dan rata-rata tidak memiliki ijin tambang, minimnya pengetahuan para penambang tentang cara ber- TI tidak menjadi masalah, asalkan mereka mau belajar, bekerja keras dan tidak menuntut karena TI yang mereka jalankan menggunakan perlatan manual, hanya dengan menggunakan mesin Robin dan tidak membutuhkan jasa operator untuk menggunakan alat berat, dan otomatis tidak mengancam keselamatan para penambang.

Hubungan unik kemudian terbentuk dari kondisi tersebut, dimana para bos TI dengan modal kecil merasa bertanggung jawab terhadap kehidupan setiap harinya para penambang karena rata-rata mereka adalah pendatang sedangkan para bos TI adalah penduduk asli daerah setempat walaupun timah yang mereka hasilkan hanya cukup untuk menutupi modal operasional TI dalam satu hari saja. Kondisi inilah yang peneliti temukan di Desa Lampur, Kabupaten Bangka Tengah. Lampur adalah bekas daerah galian PT.Timah, Tbk. yang ditinggalkan dengan alasan tidak lagi produktif dan mempunyai kandungan timah yang tinggi. Namun dengan adanya Perda No. 6/2001, masyarakat setempat berlomba-lomba menggali kembali daerah bekas galian yang sudah ditinggalkan oleh PT. Timah, Tbk. 
Hubungan yang cair antara Bos TI dan anak buah sangat cair dan tipe hubungan seperti itu umum terjadi di dunia pertambangan, khususnya penambangan TI di Kepulauan Bangka Belitung, dimana hubungan antara bos TI dan para anak buah atau para penambang hanya bergantung pada faktor ekonomi semata. Para anak buah bebas untuk berhenti bekerja kapan saja karena tidak ada kontrak yang mengikat atau ketika mereka merasa sudah tidak nyaman dan tidak lagi menguntungkan tanpa merasa bersalah ataupun terikat secara emosional. Banyak sekali terjadi para anak buah yang telah memiliki modal cukup kemudian mereka membeli mesin sendiri dan mendatangkan para penambang baru dari daerah asal mereka masing-masing. Para bos TI pun tidak merasa ditinggalkan atau sakit hati karena banyak para penambang baru yang sangat bersedia menggantikan para anak buah lama dengan upah lebih murah. Hanya segelintir para anak buah yang mau bertahan hanya pada satu bos TI.

Prinsip egalitarianisme berlaku pada pola hubungan Bos TI dengan anak buah di Desa Lampur khususnya maupun di daerahdaerah tambang di Provinsi Kepulauan Bangka Belitung umumnya. Cooper memaparkan prinsip egaliter menekankan manfaat atau kegunaan sebagai tolak ukur untuk menilai dan mengambil keputusan. Suatu tindakan atau keputusan berguna apabila semakin banyak orang yang mendapatkan keuntungan dari tindakan atau keputusan tersebut. Prinsip ini berkaitan dengan dua premis yaitu pertama, manusia memiliki kemampuan yang sama untuk mengambil manfaat, seperti pendapatan, status, premis kedua, hal-hal seperti status, pendapatan akan cenderung mengalami kekurangan manfaat bila telah mengalami tahap yang maksimum. Premis pertama hanya berlaku sebagai kebutuhan dasar manusia, karena untuk kebutuhan yang lebih tinggi setiap manusia memiliki selera dan kemampuan yang berbeda-beda. Sedangkan pada premis kedua, setiap pencapaian maksimum yang dihasilkan oleh manusia pada kenyataannya tidak akan pernah mengalami kekurangan manfaat karena setiap orang memiliki caranya sendiri untuk mencapai tingkat kepuasan maksimum kemudian mengelolanya serta hasrat untuk mendapatkan kepuasan ke tingkat yang lebih tinggi.

Berdasarkan Prinsip Egaliter tersebut dalam kaitannya dengan hubungan antara bos TI dan anak buah, prinsip kesetaraan atau egalitar berlaku ketika tingkat ketergantungan bos TI maupun anak buah sudah tidak terpenuhi maka mudah bagi mereka untuk mengambil keputusan meninggalkan kamp ataupun pekerjaaan menambang, dan ketika hubungan antara bos TI dan anak buah terputus, maka ikatan apapun diantara mereka tidak ada lagi. Hal ini dikarenakan faktor yang mengikat antara bos TI dan anak buah hanyalah faktor ekonomi semata, bahkan tak jarang terjadi ketika hubungan antara bos TI dan anak buah berubah kemudian si anak buah yang telah mendapatkan modal cukup dan membuka lahan galian serta memiliki anak buah sendiri, menjadi hubungan bos TI dengan bos TI baru yang merupakan mantan anak buah.

\section{PENUTUP}

Khusus untuk hubungan antara bos TI dengan modal kecil atau menengah dan anak buah atau para penambang di Desa Lampur, bersifat cair dan tidak mengikat secara emosional, ataupun tidak membentuk ikatan kokoh karena 
mempunyai latar belakang yang sama. Selanjutnya hubungan itu akan cepat berubah ketika tidak ada lagi hubungan kerja dan mantan anak buah berubah posisi menjadi bos TI baru. Mereka akan terus bekerja sama kalau hubungan tersebut saling menguntungkan tapi hubungan kerja akan terputus tanpa ada tuntutan apapun ketika salah satu pihak tidak lagi merasa diuntungkan. Namun hubungan yang bersifat cair dan setara tersebut tidak terjadi antara para bos TI, anak buah dengan para aparat, pengusaha dengan modal besar. Ada semacam kode tersendiri bagi para penambang yang berada di lokasi pertambangan ketika petugas akan melakukan penertiban atau razia, dan semua bos TI akan bersatu melawan penangkapan para penambang mereka. Bocornya informasi tentang akan adanya penertiban dikarenakan adanya sumber informasi dari dalam lingkungan Pemda sendiri, karena rata-rata para birokrat atau anggota dewan legislatif memiliki usaha tambang inkonvensional tersebar di seluruh lokasi tambang di Bangka Tengah maupun di luar kabupaten. Dengan para pengusaha, para bos TI dengan modal kecil maupun para anak buah merupakan ujung tombak bagi para pengusaha bermodalkan besar untuk terus mengeruk keuntungan. Para cukong hanya menerima hasil akhir bersih tanpa harus menanggung resiko karena meminjamkan modal kepada para bos TI kecil dan selanjutnya permainan tingkat elit dimulai, ketika pasir timah dengan kualitas tinggi di lepas ke pengusaha smelter kemudian di ekspor ke berbagai negara. Pola seperti itu akan terus berlangsung sampai cadangan timah di Provinsi Kepulauan Bangka Belitung tidak lagi tersisa.

\section{DAFTAR PUSTAKA}

Albrow, Martin, 2007. Birokrasi, diterjemahkan oleh M. Rusli Karim dan Totok Daryanto, Tiara Wacana, Yogyakarta.

Bertens, K., 2000. Pengantar Etika

Bisnis, Kanisius, Yogyakarta.

Black, James, 1992. Metode dan Masalah Penelitian Sosial, Eresco, Bandung.

Cooper, David, 2010. Illusions of Equality (International Library of the Philosophy of Education), New York.

Damsar, 1997. Sosiologi Ekonomi, RajaGrafindo Persada, Jakarta.

Distamben Provinsi Kepulauan Bangka

Belitung, 2003. Prospek Pengembangan Pertambangan dan Energi di Provinsi Kepulauan Bangka Belitung, Distamben Provinsi Kepulauan Bangka Belitung, Pangkal Pinang.

Dua, Mikhael, 2008. Filsafat Ekonomi

Upaya Mencari Kesejahteraan Bersama, Kanisius, Yogyakarta.

Erman, Erwiza, 2007. Deregulasi Tata Niaga Timah dan Pembuatan Negara Bayangan Lokal: Studi Kasus Bangka dalam Politik Lokal di Indonesia, editor: Henk Schulte Nordholt dan Gery van Klinken dibantu oleh Ireen Karang-Hoogenboom, Yayasan Obor Indonesia-KITLV, Jakarta. 
